\title{
GENETIC DIVERSITY OF Euterpe edulis MARTIUS BASED ON FRUIT
}

\section{TRAITS}

\author{
DIVERSIDADE GENÉTICA DE Euterpe edulis MARTIUS COM BASE EM \\ CARACTERES DE FRUTOS
}

\section{Tiago de Souza MARÇAL ${ }^{1}$; Carolina de Oliveira BERNARDES ${ }^{2}$; Wagner Bastos dos Santos OLIVEIRA ${ }^{3}$; José Henrique Soler GUILHEN ${ }^{4}$; Marcia Flores da Silva FERREIRA ${ }^{\mathbf{5}}$; Adésio FERREIRA ${ }^{\mathbf{5}}$}

1. Professor, Doutor Adjunto, Departamento de Biologia, UFLA, Lavras, MG, Brasil; 2. Doutora em Genética e Melhoramento, Departamento de Agronomia, Universidade Federal do Espírito Santo - UFES, Alegre, ES, Brasil; 3. Pós-doutor em Produção Vegetal, Departamento de Agronomia, Universidade Federal do Espírito Santo - UFES, Alegre, ES, Brasil; 4. Doutorando em Genética e Melhoramento, Departamento de Agronomia, Universidade Federal do Espírito Santo-UFES, Alegre, ES, Brasil; 5. Professor(a), Doutor(a) Associado(a), Departamento de Agronomia, CCAE/UFES, Alegre, ES, Brasil. adesioferreira@gmail.com

\begin{abstract}
Juçara (Euterpe edulis Martius) is a palm species from the Atlantic Forest whose fruits are important as a source of food to several individuals from the fauna of the region. Despite its ecological importance, juçara is found in the list of endangered species, due to the fragmentation of the forests and the illegal extraction of the heart of palm. We aimed to evaluate the inter- and intra-populational genetic diversity of $E$. edulis based on fruit and seed traits in forest fragments of the Espírito Santo State in Brazil. The aim was to generate information to be used in E. edulis breeding programs, or in the delineation of more efficient management and reforestation strategies. The study was carried out in 20 forest fragments and 198 fruit plants were sampled. Positive genetic association was observed between the evaluated traits, with the longitudinal diameter of the fruit (LDF) and the seed mass (SM) greatly affecting fruit mass (FM). The existence of interand intra-populational genetic divergence was proved. The genetic divergence found in E. edulis suggests that there is genetic material that can be explored in breeding programs and this information may also contribute to management strategies that can increase the species genetic diversity.
\end{abstract}

KEYWORDS: Euterpe edulis. Juçara. Pre-Breeding. Population genetics. Atlantic Forest.

\section{INTRODUCTION}

The genus Euterpe belongs to the Arecaceae family, which are restricted to tropical and subtropical climates, comprising the oldest individuals in the planet. This family is responsible for supplying essential resources for the survival of different communities (BARFOD; HAGEN; BORCHSENIUS, 2011; BENCHIMOL et al., 2017).

The palm trees from the genus Euterpe are significant because of their high economic and cultural value (GARCIA et al., 2019). Euterpe is comprised of seven species distributed in south and central America. Six of them are found in Brazil: $E$. edulis, E. caatinga, E. oleracea, E. longebracteata, $E$. precatoria, and E. espiritosantensis (HENDERSON, 2000; PINATUD et al., 2008). These species interact with pollinators and dispersers, performing important roles in the structure and functioning of several ecosystems (SANTOS; VARASSIN; MUSCHNER, 2018).

Among the species from the genus Euterpe, the palm tree E. edulis (commonly referred to as juçara, jussara, jiçara orripeira) deserves mention. Euterpe edulis is a native species from the Atlantic Forest found on the list of endangered species (BRASIL, 2014). Juçara naturally occurs in Brazil from Southeast Bahia and Minas Gerais to Rio Grande do Sul (LORENZI, 2010; BARFOD; HAGEN; BORCHSENIUS, 2011).

Juçara's natural regeneration is reduced by the intense exploitation it suffers due to the high nutritional and commercial value of the heart of palm that it produces (LORENZI, 2010; SCHULZ et al., 2016). In addition, the plants have a long juvenile period that lasts from 6 to 9 years, which aggravates the species scenery, hence, the felling of young plants contributes to their disappearance (CEMBRANELI; FISCH; CARVALHO, 2009).

As an attempt to remove juçara from the Brazilian list of endangered species, the commercial planting and management of fruits has been initiated. There is no need to harvest the whole plant, based on the experience with açai as a guiding model and the presence of commercial crops in the Southeast Region of Brazil, including Santa Catarina, Paraná and São Paulo, and South Bahia 
(TIBÉRIO et al., 2012; EARLING; BEADLE; NIEMEYER, 2019).

In favorable conditions, juçara is able to increase the production of fruit, producing 216-528 bunches.ha $^{-1}$, each bunch with an average of $6-5 \mathrm{~kg}$ (PALUDO; SILVA; REIS, 2012). For the purposes of economical exploitation, species variability among natural populations must be sought with the intention of finding divergent individuals that can be used in breeding programs, so that more productive and adapted genetic material can be produced (CRUZ; REGAZZI; CARNEIRO, 2012; BORÉM; MIRANDA, 2013).

Hence, we aimed to evaluate the inter- and intra-populational genetic diversity of fruit and seed traits of E. edulis in forest fragments of Espírito Santo State, Brazil. Information thus gathered could be used in the species breeding programs, or in the delineation of more efficient management and reforestation strategies, to increase genetic diversity and decrease the risk of extinction due to anthropic intervention.

\section{MATERIAL AND METHODS}

Fruits from 198 genotypes of juçara were analyzed. The genotypes were collected in 20 forest fragments located in the southern region of Espírito Santo (municipalities: Muqui (MQ) - 1 fragment; Mimoso do Sul (MI) - 3 fragments; and Jerônimo Monteiro (JM) - 1 fragment) and Caparaó (municipalities: Alegre (AL) - 8 fragments; Guaçuí (GU) - 4 fragments; and Ibitirama (IB) - 3 fragments), in Brazil. Twenty-five fruits were collected from ten genotypes in the fragments, with the exception of one of the fragments in Guaçuí, in which fruits from eight genotypes were collected.

Twenty-five fruits were evaluated from each genotype for the following traits: longitudinal and equatorial diameter of the fruit and the seed (LDF, LDS, EDF, EDS) in millimeters ( $\mathrm{mm}$ ) with the aid of a digital pachymeter of $0.01 \mathrm{~mm}$ of precision; fruit and seed mass (FM, SM) in grams (g) with the aid of an electronic scale of $0.01 \mathrm{~g}$ of precision.

The data were analyzed using the basic model of repeatability (Equation 1) that assumes the absence of design and allows the prediction of averages corrected for the permanent phenotypical effect that is equivalent to the sum of the genetic effect and the effect of the permanent environment (RESENDE, 2002).

where:

$$
\mathrm{y}=\mathrm{Xm}+\mathrm{Zp}+\mathrm{e}[1]
$$

$y:$ Vector that possesses the variable to be analyzed. $\mathrm{m}$ : Vector of measurement effects assumed as fixed and added to the general average.

p: Vector of effects of permanent environment assumed as random.

e: Vector of random errors.

$X$ : Matrix of incidence for fixed effects.

$Z$ : Matrix of incidence for the effects of permanent environment.

The principal components were estimated, based on the corrected averages, resolving the system shown in equation 2 using the matrix of covariance among the averages (S) (Equation 3) (CRUZ; REGAZZI; CARNEIRO, 2012) obtained through the variables in study, which had their averages corrected for the permanent phenotypical effect.

$$
\begin{gathered}
|\mathrm{S}-\lambda I|=0[2] \\
\mathrm{S}=\left[\begin{array}{ccccc}
\hat{\sigma}_{11}^{2} & \hat{\sigma}_{12} & \hat{\sigma}_{13} & \ldots & \hat{\sigma}_{1 p} \\
\hat{\sigma}_{21} & \hat{\sigma}_{22}^{2} & \hat{\sigma}_{23} & \ldots & \hat{\sigma}_{2 p} \\
\hat{\sigma}_{31} & \hat{\sigma}_{32} & \hat{\sigma}_{33}^{2} & \cdots & \hat{\sigma}_{3 p} \\
\vdots & \vdots & \vdots & \vdots & \vdots \\
\hat{\sigma}_{p 1} & \hat{\sigma}_{p 2} & \hat{\sigma}_{p 3} & \cdots & \hat{\sigma}_{p p}^{2}
\end{array}\right] \text { B] }
\end{gathered}
$$

where:

S: Matrix of covariance between averages.

$\lambda$ : Eigenvalues.

I: Identity matrix.

Q: Estimative of covariance.

$\hat{\sigma}^{2}$ : Estimative of variance.

The Mahalanobis distance $\left(D^{2}\right)$ was estimated, based on the corrected averages, for the permanent phenotypic effects, with regard to the average values of the twenty forest fragments. From the distance matrix, the clustering of the forest fragments was carried out by the unweighted pair group method with arithmetic mean (UPGMA), hierarchical clustering method and by the nonhierarchical Tocher Optimization method.

Subsequently, a correspondence analysis was carried out as an attempt to verify the existence of a relationship between the fruit sizes and the forest fragments where the collecting was performed, through a graphic dispersion. Fruits were classified as extra-large (EL), large (L), medium $(\mathrm{M})$, and small (S) based on the $4^{\text {th }}, 3^{\text {rd }}, 2^{\text {nd }}$, and $1^{\text {st }}$ quartiles, respectively.

The estimation of the corrected averages, principal components, clustering by the UPGMA method and correspondence analysis were carried 
out by the $\mathrm{R}$ software (R, 2016). The clustering analysis obtained by the Tocher Optimization method was performed by the Genes program (CRUZ, 2013).

\section{RESULTS AND DISCUSSION}

The two first principal components explained $93.05 \%$ of the total variation, so the study of graphic dispersion of the accessions was carried out in a two-dimensional plan (Figure 1). The longitudinal diameter of the fruits (LDF) was the trait that most influenced the discrimination of plants in the first and second principal components (Figure 1). The results obtained by the principal components analysis was considered sufficient to explain the diversity found here, since an explanation of $80 \%$ of the total variation is required for diversity studies (CRUZ; REGAZZI; CARNEIRO, 2012).

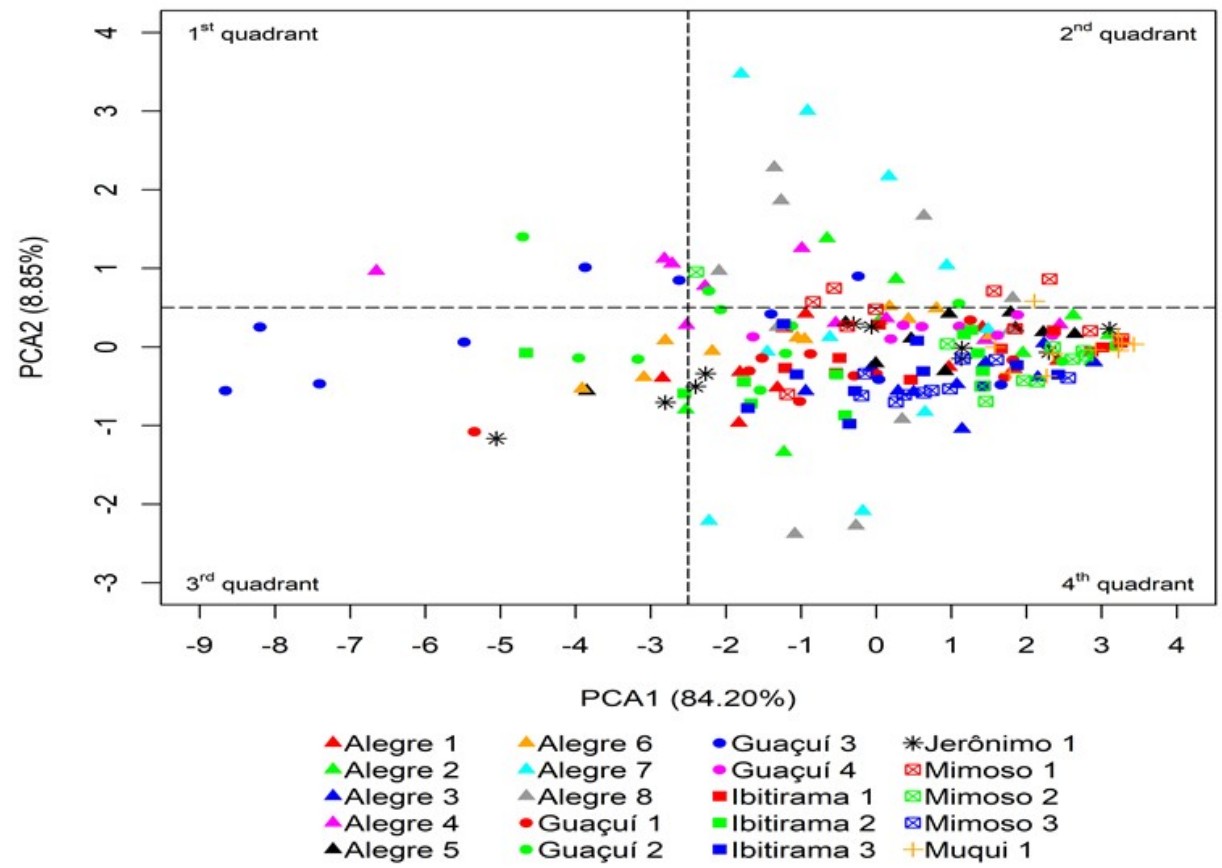

Figure 1. Graphical dispersion of the scores of the two first principal components for 198 accessions of $E$. edulis

In general, despite the geographic separation, we observed an agglomeration of a great number of plants in the second and fourth quadrants (Figure 1), where individuals from all the forest fragments are found. In these two quadrants, proximity between plants from fragments Muqui 1 and Mimoso 2 was observed, indicating low divergence within and among the two forest fragments.

Plants from Mimoso 3 were concentrated in the fourth quadrant, demonstrating the existence of low divergence in this population. This low divergence between plants is undesirable, since it may lead to an evolutive limitation of the species $>$ A decrease in the intra-populational genetic variability may cause a reduction in adaptation to environmental changes, due to an increase in crosses between related individuals (YOUNG; BOYLE; BROWN, 1996; YOUNG; BOYLE, 2000; AGUILAR et al., 2008).
Some plants from fragments Alegre1, Alegre 2, Alegre 4, Alegre 5, Alegre 6, Alegre 7, Alegre 8, Guaçuí 1, Guaçuí 2, Guaçuí 3, Ibitirama 2, Jerônimo 1, Mimoso 1 and Mimoso 2 are observed in the first and third quadrants, distancing themselves from the agglomeration of plants presented in the second and fourth quadrants, hence showing inter populational divergence. Most of the plants present in quadrants one and three originated from fragments Guaçuí 3 (6 plants), Alegre 4 (5 plants) and Guaçuí 2 (4 plants) (Figure 1).

Regarding the intra-populational divergence, fragments Guaçuí 3, Alegre 4, Guaçuí 2, Ibitirama 2, Alegre 7, Alegre 8 and Mimoso 1 may be highlighted in decreasing order of divergence.

In addition, it was observed that the municipality Guaçuí (four fragments) presented the highest level of divergence, although the sampling in the municipality has been inferior to the one carried out in Alegre (eight fragments). Alegre 
(eight fragments) also presented divergent plants, but the plants belonging to Guaçuí were shown to be very dispersed throughout the quadrants (Figure 1). The graphic distances used to discriminate between the study material worked successfully, and since genetic divergence is associated with heterosis, the analysis of genetic divergence may be useful in the preliminary choice of crosses that optimize the heterosis in breeding programs (MIRANDA et al., 2003; KEERTHI et al., 2018; HE et al., 2019).
MARÇAL et al.

The result of the principal components analysis (Figure 2) refers to the graphical dispersion of the twenty fragments evaluated, where the first two principal components explain $92.58 \%$ of the total variation. This made it possible to study the graphical dispersion of the accessions in a twodimensional plan. Fragments Alegre 3, Alegre 4, Guaçuí 3, Mimoso 1, and Muqui 1 were the ones that distanced themselves the most from the other evaluated fragments, and the largest accumulation of fragments was observed in quadrants 2 and 4.

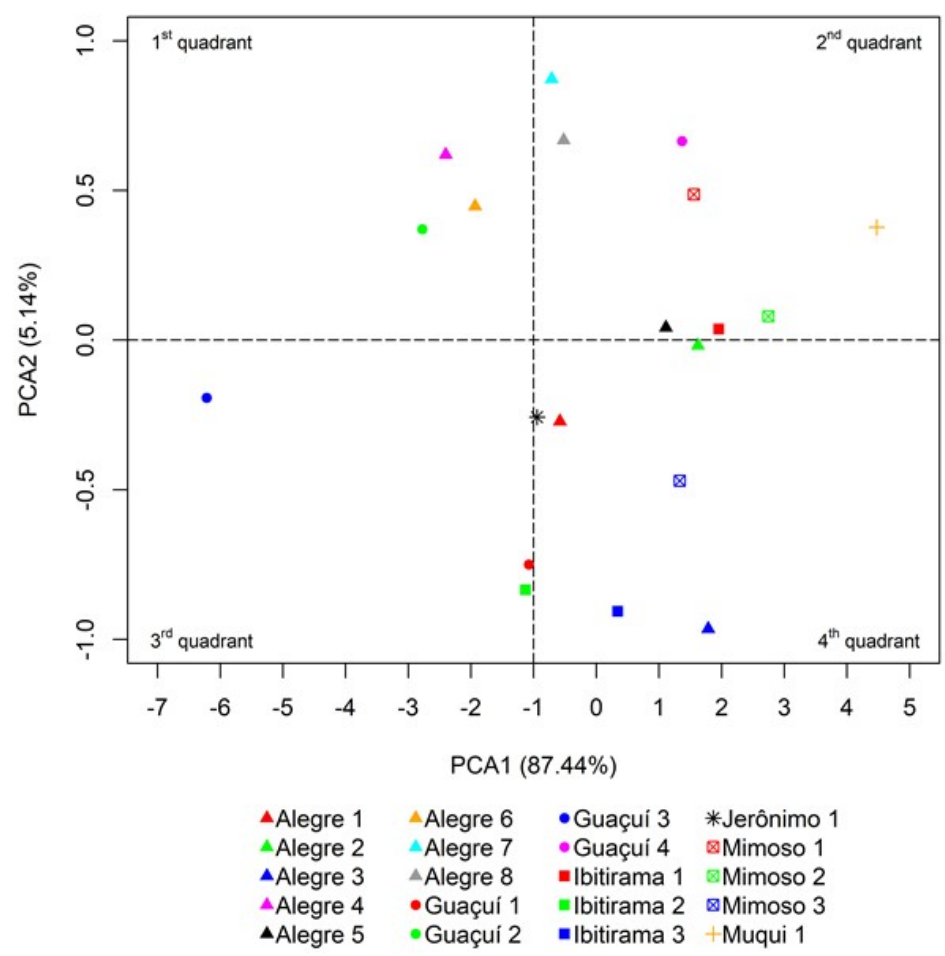

Figure 2. Graphical dispersion of the scores of the two first principal components for the twenty fragments of

$$
\text { E. edulis }
$$

The geographic location of the forest fragments did not interfere with their approximation when evaluated by principal components (Figure 2). This result is confirmed by the two most distant fragments in the principal components analysis, Guaçuí 3 and Muqui 1, which are also not the most geographically distant. This is also confirmed in Figure 1, with the accumulation of several genotypes at the margins of the respective fragments.

This randomness of similarity regarding the fragments is important, because it enables us to verify the existence of genetic diversity in micro regions evaluated in a single municipality. In addition, the greater the existing genetic diversity, the lower the risk of variability loss and possible adaptations necessary to the existent environment modifications caused by abiotic (climatic modifications) and biotic factors (deforestation, i.e., human interference) (GANGA et al., 2004).

The existence of genetic diversity at focal points implies different adaptive capacities of the analyzed accessions, which is of extreme interest for breeding programs that aim at obtaining varieties adapted to different regions or agricultural systems of the country. Moreover, the assessment of genetic divergence enables one to select combinations with greater possibilities of gene complementarity and the recovery of superior genotypes in the segregating generations (GANGA et al., 2004).

Regarding the six traits assessed for the genetic divergence between the 20 forest fragments, six groups were formed by the Tocher Optimization method (Table 1) and five groups were formed by the unweighted pair group method with arithmetic means (UPGMA) (Figure 3). 
Table 1. Evaluation of twenty fragments of E. edulis, grouped by the Tocher Optimization method.

\begin{tabular}{ll}
\hline Groups & Forest fragments \\
\hline 1 & IB1 MI2 MQ1 AL5 GU4 AL2 AL1 JM1 MI3 GU1 IB3 IB2 AL3 AL8 \\
2 & AL4 GU2 \\
3 & GU3 \\
4 & MI1 \\
5 & AL7 \\
6 & AL6 \\
\hline
\end{tabular}

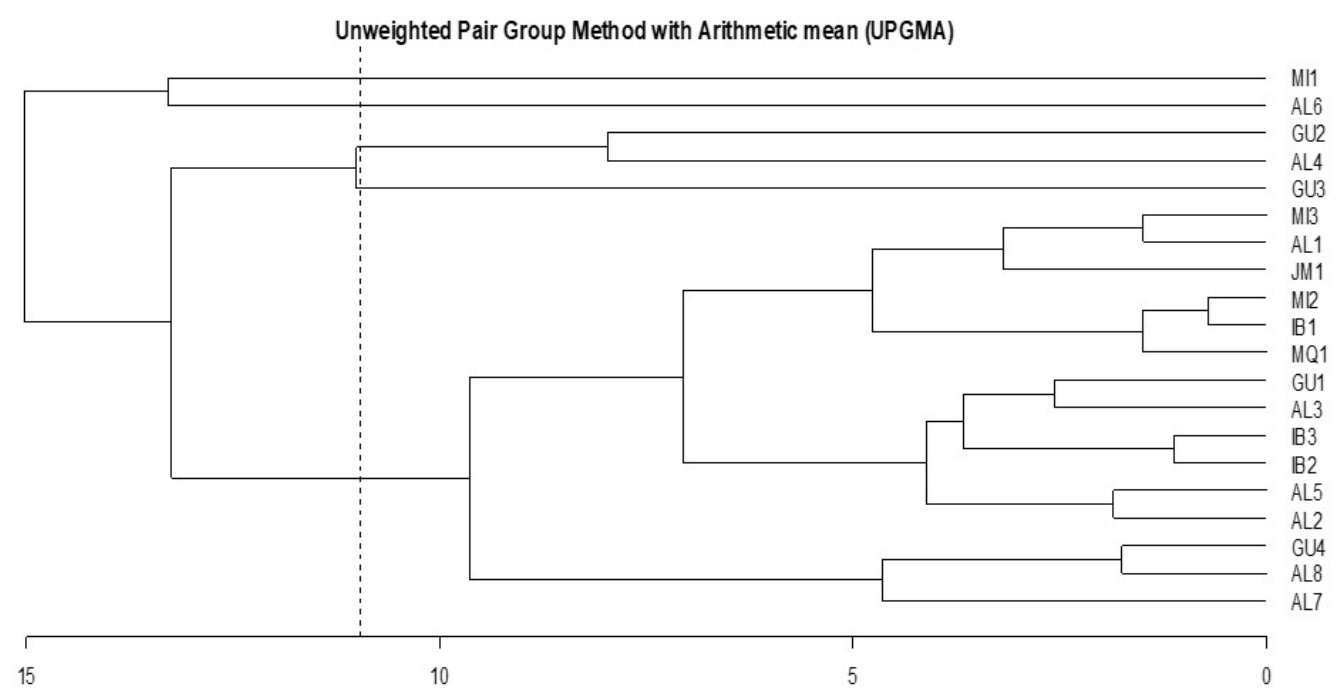

Figure 3. Evaluation of 20 fragments of E. edulis, clustered by the UPGMA method (Average link between groups)

The first group formed by the Tocher clustering method consisted of 14 fragments (IB1; MI2; MQ1; AL5; GU4; AL2; AL1; JM1; MI3; GU1; IB3; IB2; AL3; AL8) and in the clustering method UPGMA, the largest group formed consisted of the same 14 fragments, with fragment AL7 added, which was considered a unique group according to the Tocher method (Group 5).The other groups formed by the Tocher and UPGMA methods are the same: Group 2: AL4 and GU2; Group 3: GU3; Group 4: MI1 and Group 6: AL6. The presence of groups consisting of a great number of individuals may make the study of divergence more difficult, since most of the accessions belonged to only one group (NEITZKE et al., 2010; FARIA et al., 2012).

Regarding the hierarchical (UPGMA) and non-hierarchical (Tocher) cluster analyzes, it was possible to verify that the clusters formed did not consider the geographic position in which the fragments were located, since it was possible to verify a variety of regions forming group 1 and the formation of unique groups, which can also be observed in group 2, which united two fragments of distinct locations (AL4 and GU2).

The most divergent fragment was GU3, because it remained isolated by the two clustering methods (Tocher - Table 1; UPGMA -Figure 3), and by the graphic dispersion analysis of principal components (Figure 2). This was observed by its isolation from other sites, mainly by principal component1, with the highest weight, and capturing $87.44 \%$ of the variance. Thus, GU3 was the most genetically distant material.

The correspondence analysis study for the six investigated traits revealed that the fruit mass was related to the forest fragments from the Caparaó region and the fruits were of large size (Figure 4). The fragments Guaçuí 2 (GU2), Guaçuí 3 (GU3), and Alegre 4 (AL4) presented more individuals that produced extra-large fruits. Thus, they can be considered as important sources of variability and may be selected for this trait in respect of plant selection for production. 


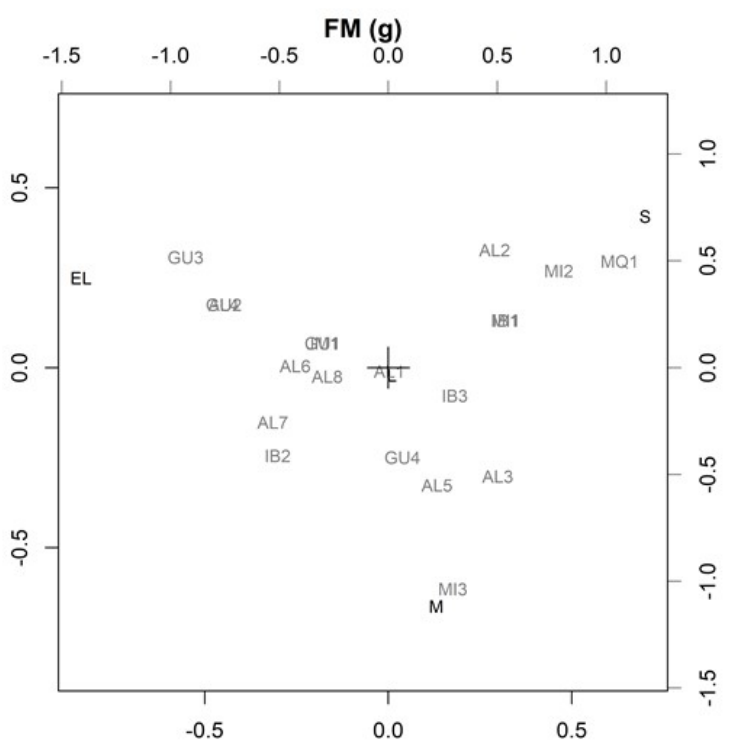

Figure 4. Correspondence analysis between fragments and the stratification of the fruit mass in extra-large (GG), large (G), medium (M) and small (S) obtained by the quartiles of each variable.

The production of medium fruit seems to be a characteristic of the accessions from MI3 and despite the geographic separation of the municipalities Alegre, Ibitirama, Mimoso and Muqui, the fragments AL2, IB1, MI1, MI2 and MQ1 all produce small fruit as a common characteristic (Figure 4).

The analyzed variables present a positive genetic association and the LDF trait possesses the greatest direct effect on the fruit mass. There is intra- and inter-population genetic divergence for $E$. edulis in the South and Caparaó regions. The three fragments showing individuals with the greatest inter- and intra-populational divergence are: Guaçuí 3, Alegre 4, and Guaçuí 2. As they also presented individuals producing extra-large fruit, they should be considered to be used at juçara's breeding programs, since they have both genetic divergence and the desired agronomic traits, which may offer a final result suitable to the consumer's demands. Mimoso 2 and Muqui 1 fragments showed the lowest dissimilarity. The natural populations of $E$. edulis studied here, presented genetic diversity and may contribute variability that can be used in species breeding programs, making the attainment of more productive and adapted genetic material possible.

\section{ACKNOWLEDGEMENTS}

The authors are grateful to the Foundation for Research and Innovation Support of Espírito Santo (FAPES), the Coordination of Improvement of Higher Level Personnel (CAPES) and the National Council of Scientific and Technological Development $(\mathrm{CNPq})$ for the financial support and opportunity to carry out this work.

RESUMO: Juçara (Euterpe edulis Martius) é uma espécie de palmeira da Mata Atlântica, que é importante como fonte de alimento para vários indivíduos da fauna. Apesar de sua importância ecológica, juçara é encontrada na lista de espécies ameaçadas à extinção, devido à fragmentação florestal e à extração ilegal do palmito. Nós tivemos como objetivo avaliar a diversidade genética inter e intra populacional de $E$. edulis com base em caracteres de frutos e sementes, em fragmentos florestais do Estado do Espírito Santo no Brasil, com o objetivo de gerar informações a serem utilizadas nos programas de melhoramento de E. edulis ou na delimitação de estratégias de manejo e reflorestamento mais eficientes. O estudo foi realizado em 20 fragmentos florestais e 198 plantas frutíferas foram amostradas. Foi observada uma grande associação genética positiva entre os caracteres avaliados, com as características diâmetro longitudinal dos frutos (LDF) e massa de sementes (SM) apresentando efeitos maiores do que a massa característica da fruta (FM). A existência de divergência genética inter e intrapopulacional foi comprovada. A divergência genética encontrada neste trabalho para E. edulis sugere a presença de material genético que vale a pena ser explorado em programas de 
melhoramento e essa informação também pode contribuir com estratégias de manejo para aumentar a diversidade genética das espécies.

PALAVRAS-CHAVE: Euterpe edulis. Juçara. Pré-melhoramento. Genética de populações. Floresta Atlântica.

\section{REFERENCES}

AGUILAR, R.; QUESADA, M.; ASHWORTH, L.; DIEGO, Y. H.; LOBO, J. Genetics consequence of habitat fragmentation in plant populations: susceptible signals in plant traits and methodological approaches. Molecular Ecology, v. 17, p.5177-5188, 2008. https://doi.org/10.1111/j.1365-294X.2008.03971.x

BARFOD, A. S.; HAGEN, M.; BORCHSENIUS, F. Twenty-five years of progress in understanding pollination mechanisms in palms (Arecaceae). Annals of Botany, v. 108, p. 1503-1516, 2011.

https://doi.org/10.1093/aob/mcr192

BENCHIMOL, M.; TALORA, D. C.; NETO, E. M.; OLIVEIRA, T. L. S.; LEAL, A.; MIELKE, M. S.; FARIA, D. Losing our palms: The influence of landscape-scale deforestation on Arecaceae diversity in the Atlantic forest. Forest Ecology and Management, v. 384, p. 314-322, 2017.

https://doi.org/10.1016/j.foreco.2016.11.014

BORÉM, A.; MIRANDA, G. V. Melhoramento de Plantas. 6. ed. Viçosa: UFV, 2013.

BRASIL. Portaria $n^{\circ}$ 443, de 17 de dezembro de 2014. Ministério do Meio Ambiente. Diário Oficial da União, Brasília, DF, 17 dez. Seção 1, 111 p.

CEMBRANELI, F.; FISCH, S. T. V.; CARVALHO, C. P. Exploração sustentável da palmeira Euterpe edulis Martius no Bioma Mata Atlântica, Vale do Paraíba - SP. Revista Ceres, v. 56, n. 3, p. 233-240, 2009.

CRUZ, C. D.; REGAZZI, A. J.; CARNEIRO, P. C. S. Modelos biométricos aplicados ao melhoramento genético. 4. ed. Viçosa-MG: UFV, 2012, 514 p.

CRUZ, C. D. Genes - a software package for analysis in experimental statistics and quantitative genetics. Acta Scientiarum Agronomy, v. 35, n. 3, p. 271-276, 2013. https://doi.org/10.4025/actasciagron.v35i3.21251

EARLING, M.; BEADLE, T.; NIEMEYER, E. D. Açai Berry (Euterpe oleracea) Dietary Supplements: Variations in Anthocyanin and Flavonoid Concentrations, Phenolic Contents, and Antioxidant Properties. Plant Foods for Human Nutrition, v. 74, p. 421-429, 2019. https://doi.org/10.1007/s11130-019-00755-5

FARIA, P. N.; CECON, P. R.; SILVA, A. R.; FINGER, F. L.; SILVA, F. F.; CRUZ, C. D.; SÁVIO, F. L. Métodos de agrupamento em estudo de divergência genética de pimentas. Horticultura Brasileira, v. 30, p. 428-432, 2012. https://doi.org/10.1590/S0102-05362012000300012

GANGA, R. M. D.; RUGGIERO, C.; LEMOS, E. G. M.; GRILI, G. V. G.; GONÇALVES, M. M.; CHAGAS, E. A.; WICKERT, E. Diversidade genética em maracujazeiro-amarelo utilizando marcadores moleculares AFLP. Revista Brasileira de Fruticultura, v. 6, n. 3, p. 494-498, 2004. https://doi.org/10.1590/S010029452004000300029

GARCIA, J. A. A.; CORRÊA, R. C. G.; BARROS, L.; PEREIRA, C.; ABREU, R. M. V.; ALVES, M. J.; CALHELHA, R. C.; BRACHT, A.; PERALTA, R. M.; FERREIRA, I. C. F. R. Chemical composition and biological activities of Juçara (Euterpe edulis Martius) fruit by-products, a promising underexploited source of high-added value compounds. Journal of Functional Foods, v. 55, p. 325-332, 2019.

https://doi.org/10.1016/j.jff.2019.02.037 
Genetic diversity...

MARÇAL et al.

HE, S.; SUN, G.; HUANG, L.; YANG, D.; DAI, P.; ZHOU, D.; WU, Y.; MA, X.; DU, X.; WEI, S.; PENG, J.; KUANG, M. Genomic divergence in cotton germplasm related to maturity and heterosis. Journal of Integrative Plant Biology, v. 61, n. 8, p. 929-942, 2019. https://doi.org/10.1111/jipb.12723

HENDERSON, A. The genus Euterpe in Brasil. In: Euterpe edulisMartius - (palmiteiro) - Biologia, Conservação e Manejo. Herbário Barbosa Rodrigues, Itajaí, 1-22, 2000.

KEERTHI, C. M.; RAMESH, S.; BYREGOWDA, M.; RAO, A. M. Frequency of Heterotic Hybrids in Relation to Parental Genetic Divergence and General Combining Ability in Dolichos Bean. Proceedings of the National Academy of Sciences, India Section B: Biological Sciences, v. 88, n. 3, p. 923-933, 2018. https://doi.org/10.1007/s40011-016-0826-8

LORENZI, H. Flora Brasileira: Arecaceae (Palmeiras). Nova Odessa-SP: Plantarum, 2010, 385 p.

MIRANDA, G. V.; COIMBRA, R. R.; GODOY, C. L.; SOUZA, L. V.; GUIMARÃES, L. J. M.; MELO, A. V. Potencial de melhoramento e divergência genética de genótipos de milho-pipoca. Pesquisa Agropecuária Brasileira, v. 38, n. 6, p. 681-688, 2003. https://doi.org/10.1590/S0100-204X2003000600003

NEITZKE, R. S.; BARBIERI, R. L.; RODRIGUES, W. F.; CORRÊA, I. V.; CARVALHO, F. I. F. Dissimilaridade genética entre acessos de pimenta com potencial ornamental. Horticultura Brasileira, v. 28, p.47-53, 2010. https://doi.org/10.1590/S0102-05362010000100009

PALUDO, G. F.; SILVA, J. Z.; REIS, M. S. Estimativas de Produção de Frutos de Palmiteiro (Euterpe edulis Mart.) a partir da Densidade de Indivíduos. Biodiversidade Brasileira, v.2, n. 2, p. 92-102, 2012.

PINATUD, J.; GALEANO, G.; BALSLEV, H.; BERNAL, R.; BORCHSENIUS, F.; FERREIRA, E.; GRANVILLE, J. J.; MEJÍA, K.; MILLÁN, B.; MORAES, M.; NOBLICK, L.; STAUFFER, F. W.; KAHN, F. Las palmeiras de América del Sur: diversidad, distribución e história evolutiva. Revista Peruana de Biologia, v. 15 , p. 007-029, 2008. https://doi.org/10.15381/rpb.v15i3.2662

RESENDE, M. D. V. SELEGEN-REML/BLUP - Seleção genética computadorizada: manual do usuário. Colombo: Embrapa - CNPF, 2002, 67 p.

SANTOS, J.; VARASSIN, I. G.; MUSCHNER, V. C. Effects of neighborhood on pollination and seed dispersal of a threatened palm. Acta Oecologica, v. 92, p. 95-101, 2018.

https://doi.org/10.1016/j.actao.2018.08.010

R Team (2013) A language and environment for statistical computing. R Foundation for Statistical Computing, Vienna, Austria. http://www.R-project.org/. Accessed in: Nov 232013.

SCHULZ, M.; BORGES, G. S. C.; GONZAGA, L. V.; COSTA, A. C. O.; FETT, R. Juçara fruit (Euterpe edulis Mart.): Sustainable exploitation of a source of bioactive compounds. Food Research International, v. 89, p. 14-26, 2016. https://doi.org/10.1016/j.foodres.2016.07.027

TIBÉRIO, F. C.; SAMPAIO-E-SILVA, T. A.; DODONOV, P.; GARCIA, V. A.; SILVA MATOS, D. M. Germination and allometry of the native palm tree Euterpe edulis compared to the introduced E. oleracea and their hybrids in Atlantic rainforest. Brazilian Journal of Biology, v. 72, p. 955-962, 2012.

https://doi.org/10.1590/S1519-69842012000500025

YOUNG, A.; BOYLE, T.; BROWN, T. The population genetic consequences of habitat fragmentation for plants. Trends in Ecology \& Evolution, v. 11, n. 10, p. 413-418, 1996. https://doi.org/10.1016/01695347(96)10045-8

YOUNG, A.; BOYLE, T. Forest fragmentation In: YOUNG, A.; BOYLE, T.; BOSHIER, D.(Ed.). Forest conservation genetics. Melborne: CISRO, 2000, p. 123-132. https://doi.org/10.1071/9780643101029 